\title{
Determination of Petroleum Hydrocarbon Contamination Tolerance Limit by Food Insect (Brachytrupes membranaceus) in Bodo Community, Niger Delta, Nigeria
}

\author{
Gbarakoro Tambeke Nornu*, Ozonma Obiageli Ukamaka \\ Department of Animal \& Environmental Biology, Faculty of Science, University of Port Harcourt, Port Harcourt, Nigeria
}

Email address:

gtambeke@yahoo.com (G. T. Nornu)

*Corresponding author

To cite this article:

Gbarakoro Tambeke Nornu, Ozonma Obiageli Ukamaka. Determination of Petroleum Hydrocarbon Contamination Tolerance Limit by Food Insect (Brachytrupes membranaceus) in Bodo Community, Niger Delta, Nigeria. Journal of Health and Environmental Research.

Vol. 5, No. 1, 2019, pp. 8-13. doi: 10.11648/j.jher.20190501.12

Received: December 16, 2018; Accepted: January 11, 2019; Published: March 19, 2019

\begin{abstract}
Petroleum hydrocarbon contaminant passes from contaminated soils to soil-inhabiting food insects and alter the tolerance limit and nutritional contents of the insects. Species samples of adult Brachytrupes membranaceus; an edible insect mostly consumed by children in the Niger Delta region of Nigeria, and its soil substrates were collected from petroleum contaminated habitat-types of 5yr-pipeline, 2yr artisanal refinery-source pollution and unpolluted sites, monthly for 6 months (May-Oct, 2017), using hand and bucket-type soil auger, at Bodo community. The samples were processed in the laboratory for Total Petroleum Hydrocarbon (TPH) and nutritional content, using KJELDAHL method and analyzed by GCFID and UV spectrophotometer analyses, respectively, to investigate human health impact of TPH contamination through insect-pathways. The results indicated that the mean values of the TPH in the soil were $1.35 \mathrm{ppm}$ (control), $373.67 \mathrm{ppm}$ (pipeline) and $351.37 \mathrm{ppm}$ (artisanal refinery) and in the crickets the values were 6.42ppm (control), 355.90ppm (pipeline) and 312.93ppm (artisanal refinery). The TPH in insects collected monthly from the control habitat-type recorded below 100ppm and those insects collected from polluted habitat-type recorded above 100ppm. Four mineral elements, $\mathrm{Fe}, \mathrm{Ca}, \mathrm{Mg}$ and $\mathrm{P}$ were detected in crickets collected from the three habitat-types. The habitat-type which contained higher TPH concentration recorded higher values of Fe (pipeline: $349 \mathrm{mg} / \mathrm{kg}$ ), Mg values was higher in artisanal refinery $(187.8 \mathrm{mg} / \mathrm{kg}$ ) and P values was higher in the control $(283.2 \mathrm{mg} / \mathrm{kg})$. The increase in levels of mineral elements, proteins and fat in polluted crickets-habitats over those of non-polluted was abnormal and hydrocarbon-induced and may cause human health implications for cricket consumers. Statistical analyses indicate a significant difference between the concentrations of TPH in the soils and crickets collected from the control and polluted habitat-types but insignificant between that of the soils and crickets collected from the same polluted habitat-types. Results implies that the TPH contained in the crickets exceeded the allowable tolerance limit by Nigerian authority, and had impact on levels of mineral elements.
\end{abstract}

Keywords: Allowable Tolerance Limit, Artisanal Refinery, Brachytrupes membranaceus, Mineral Elements, Total Petroleum Hydrocarbon

\section{Introduction}

Insects are described as valuable alternative to traditional food of animal origin, such as beef, poultry, pork, fish and eggs $[1,2]$ and so serve as good source of human mineral elements. The insect biota, Brachytrupes membranceus (giant cricket) is among 250 species of food or edible insects estimated to be consumed as food in
Africa. The insect species inhabit soil burrows, store its food, and feed on substrate comprising soil and plant parts. The insect is a pest of cultivated crops [3] grasses and it provide the alternative nutritional human requirements by converting its food into body mass, resulting in its high protein constituent. The insect also aid 
in maintaining ecosystem balance through breakdown of plant materials.

B.membranaceus, usually drag plant materials into their habitats (burrows) and in turn take nutrients through the soil profile to plant roots. Their food contains nutrients which are digested in their gut, modified and excreted as frass. Frass is a high quality input, contain $74 \%$ more available nitrogen and are deposited in the soil $[4,5]$, resulting in increased nitrogen mineralization [6]. Some crickets such as house cricket; Acheta domestica which is produced as dietary protein are used as feed for insectivores in captivity such as domestic pests or at zoos [7] have less ecological impact than conventional forms of livestock due to their comparatively efficient feed conversion [8].

Total Petroleum Hydrocarbon (TPH) defined as the measurable amount of Petroleum-based hydrocarbon in an environmental media [9] such as soil, is a term that describes several compounds contained in crude oil. The amount of TPH found in a sample is useful as a general indicator of petroleum contamination at that site. TPH enters and contaminate the soil and its inhabiting organisms through oil exploration and exploitation activities that abound Niger Delta, Nigeria [10,11]. The Bodo community is a town in Gokana Local Government Area of Rivers State in the Niger Delta region where petroleum oil pipeline belonging to Shell Petroleum Development Company (SPDC) crises cross farmlands with some youths engaged in artisanal refineries. These activities provided TPH to the soil of the community which may have impact on $B$. membranaceus that inhabit the soil, particularly on its abundance, nutrient contents, tolerance limit, and moreso, children that consume the insect as food.

Though the availability and bioaccumulation of petroleum hydrocarbons in soils and humans have low persistence and limitation respectively, it still abounds in the impacted soil. On availability, [12] reported that bioavailable petroleum hydrocarbons are unlikely to persist for a significant period of time (>years) in exposed surface soils, including near surface soils in which there is significant biological activity e.g. Garden soils. They added that higher molecular weight hydrocarbons are less available to organisms because they are less soluble in water and are more likely to sorb into the soil. Low toxicity of petroleum hydrocarbons in high organic/fine soils which promote sorption of hydrocarbons has been reported [13, 14]. In spite of this situation, B. membranaceus occur in Bodo hydrocarbon polluted soils indicating that the insect species have a high tolerance level for such pollutant, though it may exceed the tolerance limit by Nigerian Legislation.

Tolerance limit is the maximum amount of pesticides or contaminant allowed to remain in or on food and animal feed for consumption $[15,1]$. Tolerance limit for TPH is not readily available, however, there are government regulations or guidelines for some of the TPH fractions and compounds (some chemicals), which are designed to protect the public from possible harmful health effects. In Nigeria, the permissible (or not-exceed-limit) level of TPH in soil is $<2000 \mathrm{mg} / \mathrm{kg}$, in surface water $10 \mathrm{mgL}$ [16], pesticides-aldicarb, carbofuran, miral in potato (1.0$1.3 \mathrm{ppm})$, gamma $\mathrm{BHC}$ residue in fruits (3ppm) [15], Lead in Cocoa (250ppm) [17]. Edible insects and insect based food may contain hazardous chemicals similarly to other animal products [2] and these chemicals such as petroleum hydrocarbon may alter the nutritional contents of the insect, $B$. membranaceus in the soil contaminant habitat, resulting to mineral toxicity.

There is dearth of information on the impact of petroleum hydrocarbon pollution on the tolerance limit and nutritional contents of edible insects, particularly B. membranaceus in the Niger Delta, Nigeria, therefore this study was designed to evaluate the TPH contained in B. membranaceus in polluted habitat, its impact on nutritional contents, so as to provide through food insect pathway the potential human health impacts.

\section{Materials and Methods}

\subsection{Study Site}

Three sites were engaged in the study; pipeline polluted, near artisanal refinery and unpolluted (control) sites, all situated at Bodo community. The pipeline site was polluted $5 \mathrm{yr}$ prior to the study located at Bodo-west with the coordinates 4'38'12.3N and 7'16"16.57'E with an elevation of $161 \mathrm{~m}$ and referred to as station I (Figure 1). The near artisanal refinery site was a plot of cassava farm located near illegal refinery site located at 4'37'24.75" $\mathrm{N}$ and 7'16'16.25' E with elevation of $380 \mathrm{~m}$ and called station 2 (Figure 1). The control site had no petroleum oil site and was a farm bush located on 4'57 24' $\mathrm{N}$ and 7'00'46.7' $\mathrm{E}$ with elevation of $293 \mathrm{~m}$, and over $500 \mathrm{~m}$ apart from the other two sites (Figure 1).

\subsection{Study Design}

Each site was divided into 3 plots measuring $568.45 \mathrm{cmby}$ $568.45 \mathrm{~cm}$ each and separated at $100 \mathrm{~cm}$ from one another.

\subsection{Soil Sample Collection}

Soil samples were collected monthly for over a 6-month period with a soil auger to a depth of $10 \mathrm{~cm}$ from each replicate or plot. A total of 6 samples were taken each month during each collection. The samples were taken to the Entomology Research Laboratory, Department of Animal and Environmental Biology, University of Port Harcourt for analyses. In the laboratory, the soil samples were dried for $24 \mathrm{hrs}$ in the oven, ground into powder using mortar and pestle, sieved through a $2 \mathrm{~mm}$-mesh sieve.

\subsection{Insect Sample Collection}

B. membranaceus species were collected randomly from their burrows in accordance with the described methods [18]. 
The crickets caught were placed in a sterile vial and taken to the laboratory at the centre for marine pollution and seafood safety, University of Port Harcourt. The insect samples were dried for $24 \mathrm{hrs}$ in the laboratory oven (GenLab oven model mino/30), and ground into powder and sieved using $2 \mathrm{~mm}$ mesh size sieve.

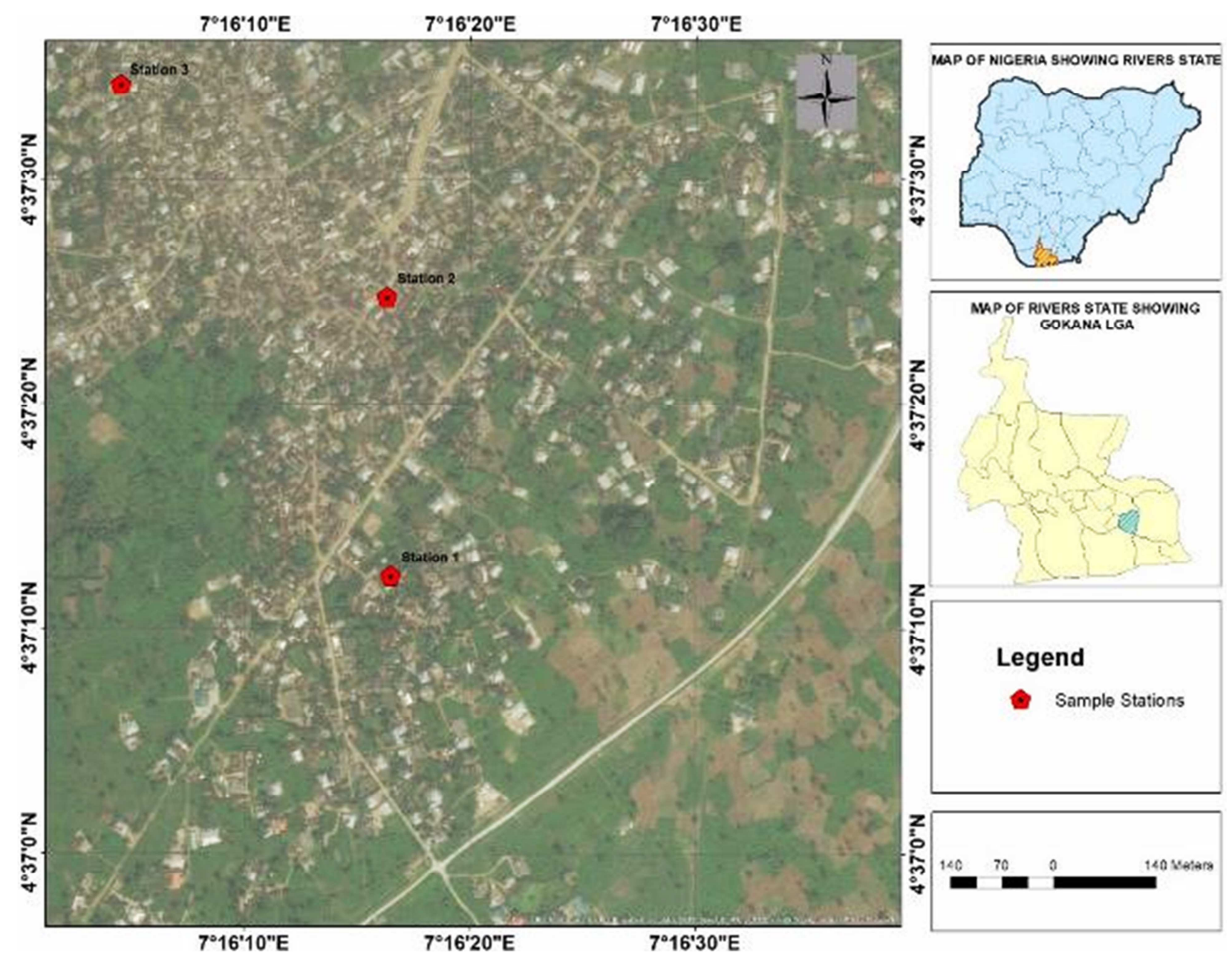

Figure 1. Map of Study Site.

\subsection{Determination of TPH Contaminant}

The extracts of the insect and soil samples prepared were separately collected in a $250 \mathrm{ml}$ standard flask and made up to mark with n-hexane, for fractionation on an absorbent column. Blank solutions were prepared by filling the samples cuvette with hexane and all the samples were placed in a sample holder of GCFID analyser. The analytical method
A $10 \mathrm{~g}$ of composite insect samples from each sites were placed in a conical flask, with $20 \mathrm{ml}$ of n-hexane added and extracted in a mechanical shaker to prepare the samples for analyses. The preparation method used include: homogenization, digestion, and solvent extraction.

\section{$7^{\circ} 16^{\prime} 30^{\prime \prime} \mathrm{E}$}

$$
\mathrm{TPH}(\mathrm{mg} / \mathrm{kg})=\frac{\text { absorbance } \times \text { Vol. } \mathrm{n}-\text { hexane } \times \text { gradient } \times 100}{\text { Wt. of sample used. }}
$$

The analyses were conducted at the laboratory of Port Harcourt. integrated service limited, Port Harcourt.

\subsection{Determination of Nutrient Content of Insects}

The ultra-volume (UV) spectrophotometer was used to analyze nutrients contained in the insect samples, at the Laboratory of Diamond Standard Integrated Service Limited, used was EPA method 8015 modified where hydrocarbons were measured by gas chromatography flame ionization detector GCFID. The wavelength was set at $425 \mathrm{~mm}$ and the transmittance adjusted to $100 \%$ (Zero absorption). The absorption of the extracted oil was taken from the gradient calibration curve, calculated using the formula:

\subsection{Determination of Soil Edaphic Factors}

Temperature $(0 \mathrm{c})$ of soil samples were taken at the study sites using-in-glass thermometer (model 860033), soil moisture content was measured [19,20], and soil PH conducted [20], and readings taken in accordance with Bate (1954) procedure. 


\subsection{Data Analysis}

Analysis of Variance (ANOVA) was used to analyze the data obtained in the study. Turkey's test (Honestly significant Difference) was done to compare means in order to attest to the significant difference of concentration of hydrocarbon contamination and nutritional status among the insect and studied sites at $\mathrm{P}>0.05$ level of significance.

\section{Results and Discussion}

\subsection{Cricket Tolerance Limit for TPH Pollution}

There was significant difference in TPH concentration between crickets collected from non-polluted and those of pipeline and artisanal refinery $(\mathrm{P}=0.0005$ Control Vs. Pipeline; $\mathrm{P}=0.0007$ Control Vs. Artisanal), but no significant difference between those of pipeline and artisanal $(\mathrm{P}=0.98)$.

The mean Total Petroleum Hydrocarbon (TPH) levels in crickets collected from the three habitat-types were $6.43 \mathrm{ppm}$, $355.9 \mathrm{ppm}$ and $312.9 \mathrm{ppm}$ in the control, pipeline and artisanal refinery, respectively (Table 1).

In the soil substrate, a similar statistical result was obtained between samples collected from non-polluted and the two polluted habitat-types at $\mathrm{P}<0.05$ ( $\mathrm{P}=0.001$ Control Vs. Pipeline and Control Vs. Artisanal; and $\mathrm{P}=0.89$ pipeline Vs. artisanal refinery). The mean values of soil TPH in the control, pipeline and artisanal refinery was $1.35 \mathrm{ppm}$, $373.67 \mathrm{ppm}$ and $351.37 \mathrm{ppm}$ respectively. The result indicated that the soil and cricket TPH from the respective habitattypes was $2242 \mathrm{ppm}$ and $2135 \mathrm{ppm}$ (pipeline habitat-type), $2108.20 \mathrm{ppm}$ and $1877.60 \mathrm{ppm}$ (artisanal) and $8.12 \mathrm{ppm}$ and $38.57 \mathrm{ppm}$ (control) (Table 1).

The significant difference in Total Petroleum Hydrocarbon level between crickets collected from the control and polluted habitat-types indicated that though $B$. membranaceus could tolerate a high level of TPH, it exceeded the tolerance limit This also occur in the soil samples collected from the control and the polluted habitat-types. The permissible limit of TPH in soil samples is $<2000 \mathrm{mg} / \mathrm{kg}$ [16] and that obtained in the present study is 2242ppm (pipeline) and 2108ppm (near artisanal refinery). In potato and fruits, pesticides such as Carbofauran, gamma BHC, have permissible limit between $1.0-3 \mathrm{ppm}$ [15]. The TPH in B. membranaceus was $2135.40 \mathrm{ppm}$ (pipeline) and $1877 \mathrm{ppm}$ (near artisanal refinery) and the total number of insects analyzed was 270 , indicating $7.9 \mathrm{ppm}$ and $6.95 \mathrm{ppm}$ in each insect collected from pipeline and near artisanal refinery, respectively. These exceeded the tolerance limit of 3ppm for potato.

Though the level of TPH in the insect exceeded the tolerance limit, the insect still dwell in the polluted habitattype, due partly to the concepts that the TPH level is below the insect toxic level or the insect possess the capacity to withstand or compensate the stress because it can utilize petroleum hydrocarbon as an energy source [21]. Insect abundance was not studied, but the results showed that $B$. membranaceus tolerated the pollutant indicating a support to the concept that individual polycyclic aromatic hydrocarbons (PAH) (a close substance to TPH) concentrations that are Toxic to soil-dwelling species are in the range of 20$100 \mathrm{mg} / \mathrm{kg}$ as quoted in $[22,23]$. The result obtained in this present study showed a transfer of pollutant from the soil to the insect, with the concentration below the toxic range that will eliminate the insect completely.

United Nations Environment Programme (UNEP) [24] reported that Petroleum hydrocarbons are not effectively taken up by plants or animals, and finfish because they metabolize PAHs, preventing accumulation in edible tissue. Invertebrates particularly insects have this metabolizing capacity which enable B. membranaceus to withstand the pollutant.

Landsdell and McConnell, [12] reported that TPH bio accumulate to a limited extent in earthworms and invertebrates because they have low level of metabolizing TPH, but higher animals (eg. mammals) readily metabolize petroleum hydrocarbons. The result of our study agrees with the concept that the insect tolerated the polluted habitat-types as a result of low metabolizing ability, while the human metabolizing ability is within TPH tolerance limit, which has been exceeded.

Table 1. Concentration of TPH (ppm) in the Substrates at the Habitat-types During the Period of Study.

\begin{tabular}{lllll}
\hline Habitat-types (Sites) & & Total & Mean & S.E. \\
\hline Control & Soil & 8.12 & 1.35 & 0.064 \\
& Insect & 385.58 & 64.26 & 0.87 \\
Pipeline & Soil & 2242.00 & 373.67 & 120.35 \\
& Insect & 2135.40 & 355.90 & 121.14 \\
Near artisanal refinery & Soil & 2108.20 & 351.37 & 108.37 \\
& Insect & 1877.60 & 312.93 & 65.27 \\
\hline
\end{tabular}

The number of adult crickets caught on each day of sampling in the polluted habitat-types was 15 to 35 , totaling 270 species of $B$. membranaceus analyzed in the study. Forty-two species were engaged in the control.

\subsection{Impact of Hydrocarbon Pollution on Level of Mineral Elements, Proteins and Fats in the Biota (B. membranaceus)}

Statistical analyses among the level of nutrients indicated a significant difference between phosphorus and iron, calcium and magnesium $(\mathrm{P}>0.005)$ at the three habitat-types. The level of phosphorus in the polluted habitat-type was relatively low; $0.39 \mathrm{mg} / \mathrm{kg}$ (pipeline), and $0.87 \mathrm{mg} / \mathrm{kg}$ (artisanal) (Table 2).

The levels of iron, magnesium and calcium in crickets collected from the habitat-types was high in the pipeline, followed by those of artisanal and low in the control (Table 2). A total of $469.8 \mathrm{mg} / \mathrm{kg}$ (35.24\%) of iron content of the mineral elements in crickets, calcium $179.2 \mathrm{mg} / \mathrm{kg}(13.44 \%)$, was recorded across the habitat-types. Out of the total of $469.8 \mathrm{mg} / \mathrm{kg}$ (Iron) contained in the crickets collected across the three habitat-types, pipeline alone recorded $349 \mathrm{mg} / \mathrm{kg}$ representing $83.87 \%$. 
Table 2. Relative Total Levels of Mineral Elements in Crickets at the Habitat-types During the Period of Study.

\begin{tabular}{|c|c|c|c|c|c|}
\hline \multirow{2}{*}{ Habitat-types } & \multicolumn{5}{|c|}{ Levels of Mineral Elements $\mathrm{mg} / \mathrm{kg}$} \\
\hline & $\mathbf{F e}$ & $\mathbf{C a}$ & Mg & $\mathbf{P}$ & Total \\
\hline Control & 49.3 & 34.9 & 49.4 & 283.2 & 416.8 \\
\hline Pipeline & 349 & 97.9 & 171.3 & 0.39 & 618.19 \\
\hline Near Artisanal refinery & 71.5 & 46.4 & 187.8 & 0.87 & 306.57 \\
\hline Total & 469.8 & 179.2 & 408.5 & 284.46 & 1341.56 \\
\hline$\%$ age & 35.24 & 13.44 & 30.06 & & 21.33 \\
\hline
\end{tabular}

Table 3 indicates that pipeline habitat-type recorded in $\mathrm{mg} / \mathrm{kg} 58.17 \pm 22.53$ (Iron), $16.32 \pm 4.53$ (Calcium), $28.55 \pm 12.01$ (Magnesium) and $0.07 \pm 0.01$ (Phosphorus). In the control, Iron (8.22 \pm 0.11$)$, phosphorus (47.2 \pm 0.09$)$ (Table 3).

Table 3. Mean \pm Standard Error of Nutrient Concentration Across Study Sites.

\begin{tabular}{llllll}
\hline Sites & Fe & Ca & Mg & P & f-value \\
\hline Control & $8.22 \pm 0.11$ & $5.81 \pm 0.04$ & $8.23 \pm 0.09$ & $47.21 \pm 0.09$ & 9903.754 \\
Pipeline & $58.17 \pm 22.53$ & $16.32 \pm 4.53$ & $28.55 \pm 12.01$ & $0.07 \pm 0.01$ & 31.57395 \\
Artisanal & $11.92 \pm 5.90$ & $7.73 \pm 2.98$ & $31.31 \pm 21.57$ & $0.14 \pm 0.02$ & 12.12873 \\
\hline
\end{tabular}

The percentage of protein, fat and vitamin $\mathrm{C}$ contained in the cricket at the habitat-types is recorded on Table 4 and it showed that pipeline had the highest levels among the habitat-types (Table 4). The concentration of these food types was low in the control; 39.05\% (protein), 5.19\% (fat) and 3.16mg/L (vitamin C) (Table 4).

Table 4. Mean Level of Food types (Protein, fat and Vitamin C) in Crickets (Biota) During the Period of study.

\begin{tabular}{llll}
\hline Sites & \% Protein & \%Fat & Vit.C (mg/L) \\
\hline Control & 39.05 & 5.19 & 3.16 \\
Pipeline & 111.60 & 13.44 & 790.55 \\
Near Artisanal Refinery & 95.07 & 4.54 & 734.42 \\
\hline
\end{tabular}

The result showed an increase in the level of mineral elements in edible B. membranaceus caused by Total Petroleum Hydrocarbon (TPH). This increase when compared with the control can be termed abnormal as it exceeded those of the control. The above-level TPHtolerance limit recorded in insects collected from the polluted habitat-types caused the abnormal mineral, protein, fat and vitamin C levels in B. membranaceus.

This petroleum hydrocarbon induced minerals are contained in the crickets consumed by the children and adults of Bodo Community and the people of the entire Niger Delta. The excessive or abnormal level of mineral elements can cause a lot of human health implications, collectively referred to as mineral toxicity. Mineral toxicity is a condition in which the concentration in the body of any one of the minerals necessary for life is abnormally high, and which has an adverse effect on health [25]. Hydrocarbon induced high levels of iron, calcium, protein, fats and potassium recorded in this study can lead to vomiting, diarrhea, abdominal pains, liver damage and other human health implications [26].

\section{Conclusion}

Species samples of adult Brachytrupes membranaceus_an edible insect mostly consumed by children in the Niger Delta region of Nigeria and its soil substrates were collected from petroleum contaminated habitat-types and analysed for TPH and nutrient composition, using standard methods. The results showed that the TPH concentration in the insects was above the allowable tolerance limit by Nigeria legislation.
The nutrients were hydrocarbon-induced, and resulted to abnormal concentrations. The crickets contained human TPH intolerant limit and abnormal concentration of nutrients, which if not properly checked as a food pathway, could cause serious health implications particularly mineral toxicity on cricket consumers in the Niger Delta.

\section{References}

[1] FAO (2013). The state of Food Insecurity in the World, Addressing Food Security in Food and Agricultural Organization of the United Nations, Rome.

[2] EFSA (2015). (European Food Safety Authority) Scientific Opinion on risk profile related to Production and consumption of Insects as Food and Feed. http.,//dx.doi.org/10.2903/j.efsa.2015.4257.

[3] Banjo, AD, Lawal, OA, Songonuga EA (2006). The nutritional value of fourteen species of edible Insects in South western Nigeria. Afr. J. Biotechnol. 5 (3): 298-301.

[4] Madritch, MD, Donaldson JR, and Lindroth RL (2007). Canopy herbivory can mediate the Influence of plant genotype on soil processes through frass deposition. Soil Biol. Biochem 29:1192-1201.

[5] Schowalter, TD (2000). Insect Ecology: An Ecosystem Approach. Academic Press, New York.

[6] Reynolds, B. C, Hunter, MD, and Crossley, DA Jr (2000). Effects of Canopy herbivory on nutrient.

[7] Van Huis, A. (2013). Potential of Insects as Food and Feed in assuring Food Security. Ann. Rev. Entomol. 563-583. 
[8] Lundy, ME, and Parrella MP (2016), Crickets are not a Free Lunch: Protein capture from Scalable Organic side-streams via High Density Populations of Acheta domesticus doi:10.1371/journal.pone.0118785.

[9] ATSDR, (1999) Agency for Toxic Substances Disease Registry. Toxicological Profile for Total Petroleum Hydrocarbons (TPH). US Department of Health and Human Services, Atlanta, GA. Available at www.atsdr.cdc.gov/Tox profiles/tp 123-p.pdf.

[10] Ekundayo, E. O., and Obiekwe, C. O (1997). Effects of an oil spill on soil physic-chemical properties of a spill site in typical pale-adult of mid-western Nigeria. Environmental and Assessment, 45:209-221.

[11] Iwegbue, C. M. A., Nwajei. G. E, and Arimoro, F. O. (2007). Characteristic level of Total Petroleum Hydrocarbon in Soil, sediment and surface water of an oil impacted area in the Niger Delta. Pakistan Journal of Scientific and Industrial Research. 50 (4) 247-250.

[12] Landsdell and McConnell (2003). Ecological Considerations in Setting Soil Criteria for Total Petroleum Hydrocarbons $(<\mathrm{C} 15)$ and Napthalene. In proceedings of the fifth National Workshop on the Assessment of site contamination eds. Langley, A, Gilbey, M and Kennedy, B.

[13] Salanitro et al., Crude oil Hydrocarbons Bioremediation and soil Ecotoxicity Assessment, Environmental Science and Technology 31 (6): 1769-1776.

[14] Dorn et al (1998). Assessment of Acute Toxicity of Crude oils in soils using Earthworms microtox (R), and plants, chemosphere 37 (5): 845-860.

[15] NAFDAC (1996). National Agency for Food and Drug Administration and Control. Pesticide Registration Regulations, B 303- B307.

[16] EGASPIN (1992). Environmental Guidelines and Standards for the Petroleum Industries in Nigeria, issued by the Department of Petroleum Resources (DPR), Nigeria and
Global Legal Revised Edition, (2002) Group Limited, London, UK.

[17] FAO (1968). Food and Agricultural Organization of the United Nations. Pesticide Residues in Food. 19pp.

[18] Ogbalu, O. K and Renner, R. N. (2015). Microbiological Investigations on Gryllotalpa Africana (Orthoptera: Gryllotalpidae), an Edible Cricket of the Niger Delta. Journal of Pharmacy and Biological Sciences. Vol. 10, Issue I Ver. II, pp38-42.

[19] Iloba, B. N. \& Ekrakene T. (2008). Soil microarthropods Associated with mechanic workshop soil in Benin City, Edo State, Nigeria, Res. J. of Agric. Biol. Sc. 4 (1): 40-45.

[20] Gbarakoro T. N, Okiwelu, S. N., Umeozor, O. C., and Badejo, A. (2011). Soil microarthropods in a Secondary Rainforest, Rivers State, Nigeria-III-Partial Recovery after an Oil Spill. Int. Journal of Ecosystem 1 (1):1-4.

[21] Song, H., Wang, X., Bartha, R., (1990). Bioremediation Potential of Terrestrial Fuel Spills. Appl. Environ. Microbiol. $56,652-656$.

[22] WHO (1998). (World Health Organization) Environmental Health Criteria 202: Selected Non-heterocyclic Polycyclic Aromatic Hydrocarbons, Wissenschaftliche Verlagsgesekkschaft, stuggart. World Health Organization, Geneva.

[23] Sverdrup, L. E. et al (2002). Effects of Eight polycylic aromatic compounds on the survival and Reproduction of Enchytracus crypticus. Environmental Toxicology and Chemistry 21 (1):109-114.

[24] UNEP (2011). United Nations Environment Programme: Environmental Assessment of Ogoniland Publ. UNEP, Nairobi Kenya. 257pp

[25] www.health of children.com/m/mineral-toxicity.html, 2018.

[26] https://healthy eating.sfgate.com/dangers-excessive nutrients6262. 